\title{
11. NEOGENE AND QUATERNARY SILICOFLAGELLATES FROM THE CENTRAL PACIFIC OCEAN (DSDP LEG 33)
}

\author{
Erlend Martini, Geologisch-Paläontologisches Institut der Universität Frankfurt a. M., Germany
}

\section{INTRODUCTION}

During Leg 33 of the Deep Sea Drilling Project five sites (314 to 318 ) were occupied and eight holes drilled between Hawaii and Tahiti in the Central Pacific Ocean. Material from two sites (315 and 316) yielded silicoflagellates and diatoms sufficient for detailed investigation, whereas the recovered sediments from Sites 314, 317 , and 318 are barren of silicoflagellates.

Increased interest in silicoflagellate biostratigraphy and systematics in the last few years is indicated by a large number of papers dealing with this subject, most of them based on material recovered by the Deep Sea Drilling Project. Since the first investigation of continuous deep-sea sequences (Martini, 1971a, b), the knowledge of the distribution and diversity of silicoflagellate assemblages has been considerably broadened, especially through the studies of Bukry (1973a-d, 1974a, b); Dumitrica (1973a, b); and Ling $(1970,1972,1973)$ on the basis of deep-sea material, and Bachmann (1970, 1971a, b) and Martini (1972a, b, 1974) on the basis of land sections and localities. The systematics of silicoflagellates, on the other hand, shows little improvement. This is indicated by the use of a variety of names for the same taxa as a result of badly figured species, overemphasis of aberrant forms, and unknown or insufficient data on localities and their stratigraphic position. Fortunately, the Ehrenberg collection, which encompasses a large number of silicoflagellates, survived the last war and is now housed in the Museum für Naturkunde der Humboldt-Universität in Berlin. An investigation and documentation of the type material have been completed and will be published in the near future by Locker. It is hoped that the paper by Locker will clear up many of the misinterpretations and uncertainties in the silicoflagellate field.

\section{LOCALITIES AND ASSEMBLAGES RECOVERED}

Geographical positions of the DSDP sites drilled during Leg 33 are as follows (see also Figure 1):

\begin{tabular}{|c|c|}
\hline 314 & $\begin{array}{l}\text { lat } 15^{\circ} 54.76^{\prime} \mathrm{N} \text {, long } 168^{\circ} 28.07^{\prime} \mathrm{W} \text {, } \\
\text { water depth } 5213 \text { meters }\end{array}$ \\
\hline Holes $315,315 \mathrm{~A}$ & $\begin{array}{l}\text { lat } 4^{\circ} 10.26^{\prime} \mathrm{N} \text {, long } 158^{\circ} 31.52^{\prime} \mathrm{W} \text {, and } \\
158^{\circ} 31.54^{\prime} \mathrm{W} \text {, water depth } 4152 \text { meters }\end{array}$ \\
\hline Site 316 & $\begin{array}{l}\text { lat } 0^{\circ} 05.44^{\prime} \mathrm{N}, \text { long } 157^{\circ} 07.71^{\prime} \mathrm{W} \text {, } \\
\text { water depth } 4451 \text { meters }\end{array}$ \\
\hline Holes $317,317 \mathrm{~A}, 317 \mathrm{~B}$ & $\begin{array}{l}\text { lat } 11^{\circ} 00.09^{\prime} \mathrm{S} \text {, long } 162^{\circ} 15.78^{\prime} \mathrm{W} \text {, } \\
\text { water depth } 2598 \text { meters }\end{array}$ \\
\hline Site 318 & $\begin{array}{l}\text { lat } 14^{\circ} 49.63^{\prime} \mathrm{S} \text {, long } 146^{\circ} 51.51^{\prime} \mathrm{W} \text {, } \\
\text { water depth } 2641 \text { meters }\end{array}$ \\
\hline
\end{tabular}

As noted above, only the equatorial Sites 315 and 316 yielded silicoflagellates in the upper part of the drilled sections.

In Hole 315 silicoflagellates occur in varying numbers in all cores, indicating the presence of the Dictyocha aculeata Zone (Core 1), Mesocena quadrangula Zone (Cores 2 and 3), and Dictyocha fibula Zone (Core 4). In Hole $315 \mathrm{~A}$ silicoflagellates were encountered down to Core 5, with the Dictyocha fibula Zone present in Cores 1 and 2, the Dictyocha rhombica Zone in Core 3 and possibly in Core 4, and the Dictyocha triacantha Zone (?) in Core 5. With the decrease of the diatom population in Core 4 and below Core 5, silicoflagellates become extremely rare or disappear. The population in samples from Core 5 is rather small and monotonous, and the tentative placement in the Dictyocha triacantha Zone is deduced from the nannoplankton Zone NN 5 (Sphenolithus heteromorphus Zone), which is present at this interval.

At Site 316 silicoflagellates occur commonly only in Cores 1 to 3 , and as usual, are associated with diatoms (Plate 2, Figures 7, 8). The assemblages are of low diversity owing to the equatorial position of Site 316. The Dictyocha aculeata Zone and Mesocena quadrangula Zone are present in Core 1, and the Dictyocha rhombica Zone has been identified in Core 2 and the upper part of Core 3. In Core 3 an unconformity with several nannoplankton zones missing marks the lowest common occurrence of silicoflagellates. Below, only a single specimen of Dictyocha cf. rhombica was found in Core 3, Section 2 at $30-31 \mathrm{~cm}$, and probably belongs in the Dictyocha triacantha Zone as indicated by the nannoplankton of this particular sample. Correlation of Sites 315 and 316 and silicoflagellates identified in samples from these sites are shown in Figure 2 and Tables 1 and 2.

\section{NEOGENE AND QUATERNARY SILICOFLAGELLATE ZONATION AND COMPARISON WITH ZONATIONS OF OTHER FOSSILS GROUPS IN THE PRESENT MATERIAL}

The silicoflagellate zonation used during Leg 33 has been described in detail by Martini (1971a, b, 1972a, b) with the additional Dictyocha aculeata Zone described by Dumitrica, 1973, and includes the following zones from top to bottom:

Dictyocha aculeata Zone (base = last $M$. quadrangula) Mesocena quadrangula Zone (base $=$ first $M$. quadrangula)

Dictyocha fibula Zone (base $=$ change in frequency of $D$. rhombica and D. fibula; D.f. $>$ D.r.)

Dictyocha rhombica Zone (base $=$ last $D$. triacantha)

Dictyocha triacantha Zone (base $=$ last $N$. quadrata)

As shown in Figure 3, a number of silicoflagellate zonations have been applied in different areas by various authors, indicating somewhat better time resolution in the Northern Pacific (Ling, 1973) and Eastern 


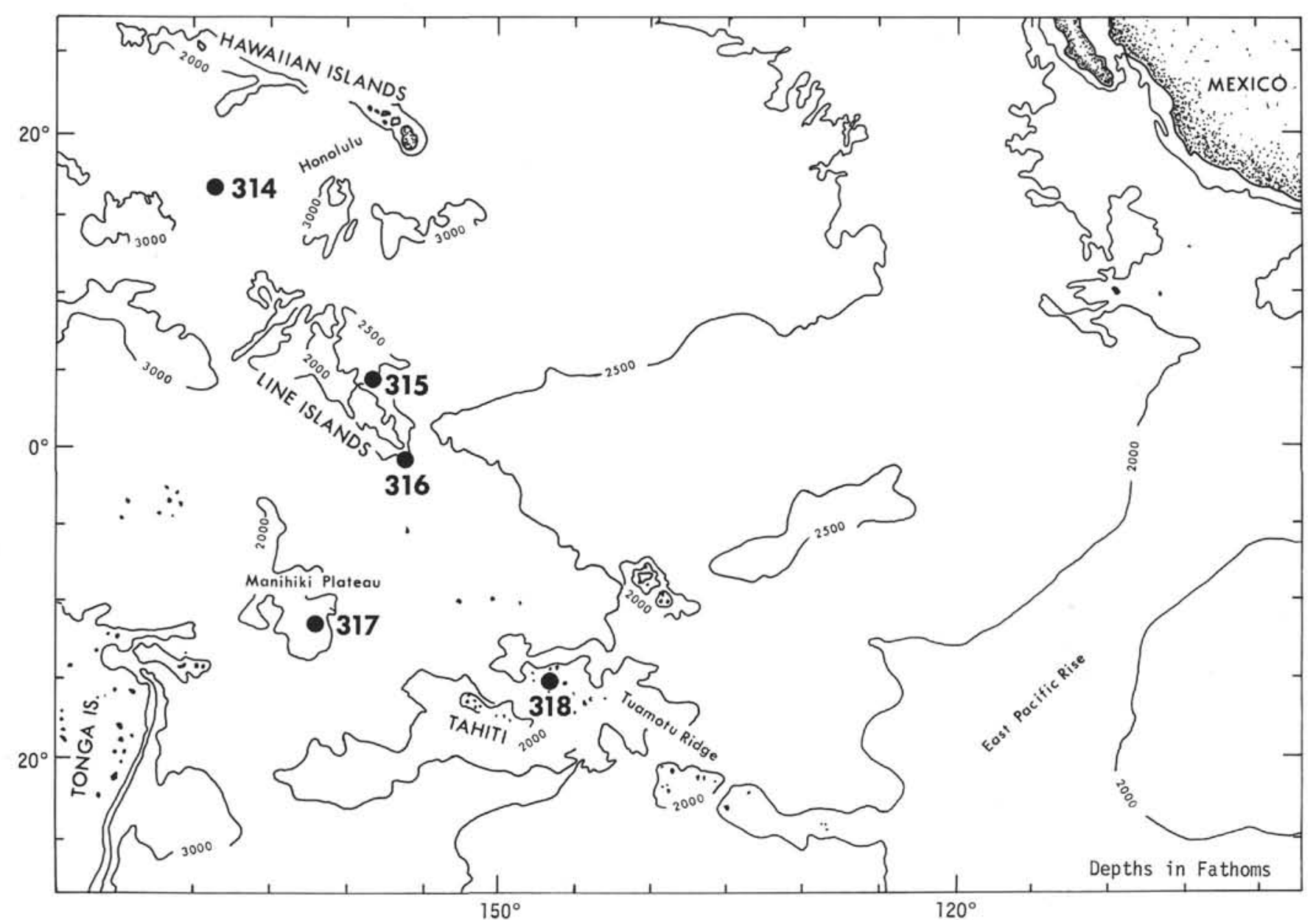

Figure 1. Sites occupied during Leg 33 in the Central Pacific Ocean. Silicoflagellates were encountered only at Sites 315 and 316.

Pacific (Bukry and Foster, 1973) than in the Central Pacific (Martini, 1971a, b, present paper) or Europe (Sanfilippo et al., 1973). However, all silicoflagellate zonations show a surprisingly low resolution in the upper Miocene, as does the nannoplankton zonation, in which the Discoaster quinqueramus Zone (NN 11) encompasses a time interval of approximately $4.5 \mathrm{~m} . \mathrm{y}$., and in which only recently some additional species suitable for a further subdivision have been found in certain areas. Also, the reported occurrences of some species (e.g., D. pseudofibula) in deep-sea cores lead to the suspicion that they have a wedge-shaped occurrence in a time/space model.

Although the silicoflagellate occurrences at Sites 315 and 316 cover only the late Miocene to Quaternary interval, and cores are irregularly spaced, some correlations with other fossil groups are possible in the present material. According to revised shipboard identifications and Schrader (this volume), the base of the Dictyocha aculeata Zone is in the higher part of Zone NN 19 (Pseudoemiliania lacunosa Zone) of the standard nannoplankton zonation (Martini, 1971a, b) and in the upper part of the diatom Nitzschia reinholdii Zone (Burckle, 1972). The base of the Mesocena quadrangula Zone is within an uncored interval, and no correlations are available. The base of the Dictyocha fibula Zone ( $D$.
rhombica/D. fibula datum) was found to be within standard nannoplankton Zone NN 11 (Discoaster quinqueramus Zone), within the foraminiferal Globorotalia acostaensis Zone (N16), within the radiolarian Ommatartus antepenultimus Zone, and in the lower part of the diatom Nitzschia porteri Zone. Earlier correlation of the base of the D. fibula Zone (Martini, 1971a, b) to the nannoplankton zonation was based on samples from the Swedish Deep Sea Expedition Station 76. However, reexamination of Sample $509-509.5 \mathrm{~cm}$ revealed rare specimens of Discoaster quinqueramus and early forms of Ceratolithus tricorniculatus, indicating that this sample belongs in Zone NN 11 (Discoaster quinqueramus Zone) rather than Zone NN 10 (Discoaster calcaris Zone). Therefore, the old correlations have to be corrected inasmuch as the base of the Dictyocha fibula Zone is in the lower part of nannoplankton Zone NN 11 (Discoaster quinqueramus Zone). The base of the Dictyocha rhombica Zone in Hole $315 \mathrm{~A}$ is within an uncored interval and at Site 316 is obscured by an unconformity with several nannoplankton zones missing.

\section{SILICOFLAGELLATE SURFACE ORNAMENTATION}

Surface ornamentation of Neogene and Quaternary silicoflagellates has been described by several authors 


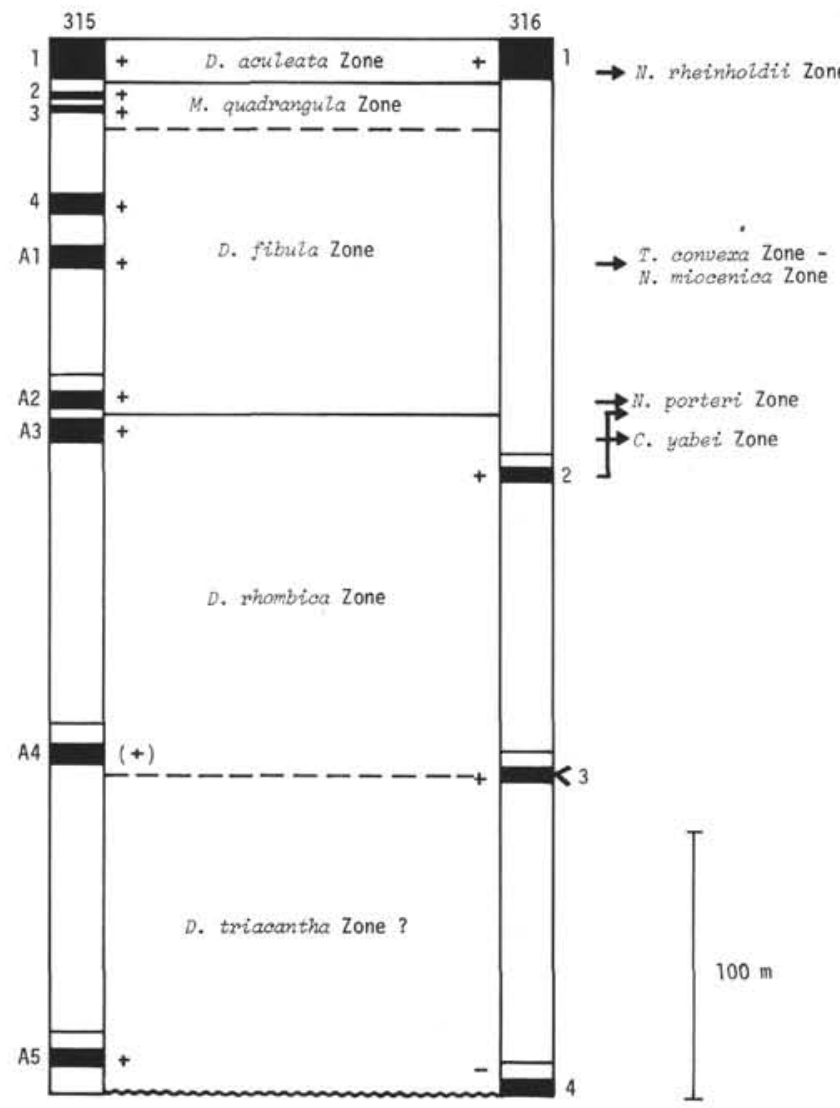

Figure 2. Correlation of Sites $315,315 A$, and 316 based on silicoflagellates, indication of silicoflagellate zones (Martini, 1971) and position of certain samples in the East Pacific diatom zonation (Burckle, 1972) $+=$ silicoflagellates common, $(+)=$ rare, $-=$ missing, $<=$ unconformity.

(e.g., Deflandre, 1950; Jerković, 1969; Bachmann and Keck, 1969) as being a network of crests and depressions in most species investigated. Some are shown to lack surface ornamentation like some specimens in the aberrant genus Deflandryocha (Jerković, 1969) or have only knots on the surface of the skeleton like in Dictyocha (=Distephanus) speculum (Wornardt, 1971). Neogene and Quaternary silicoflagellates recovered during Legs 7 and 33 in the equatorial Pacific in nearly all specimens examined under the scanning electron microscope show no signs of crests and depressions, but exhibit small knots on an otherwise smooth surface, and include the following species: Dictyocha aculeata (Plate 2, Figures 3a, b); Dictyocha messanensis (Plate 2, Figures 2a, b); Dictyocha fibula (Plate 2, Figure 4); Dictyocha rhombica (Plate 2, Figure 6); and Mesocena quadrangula (Plate 2, Figures 5a, b). Only a single specimen of Dictyocha fibula shows faint surface ornamentation of crests and depressions (Plate 2, Figures 1a, b). Comparative material from Sepulveda (Los Angeles, California) shows the netlike surface ornamentation in Dictyocha fibula and ornamentation by small knots in Dictyocha speculum, Dictyocha pseudofibula, and Mesocena circulus. Bachmann and Keck (1969, p. 206) discussed the problems of origin of the surface ornamentation and seem to favor the idea that skeletons of adult
TABLE 1

Distribution of Silicoflagellates at Site 315



Note: Numbers refer to specimens found in 10 rows of approximately $30 \mathrm{~mm}$ length on a routine smear slide viewed with an ocular $12.5 \mathrm{X}$ and an objective $25 \mathrm{X}$.

silicoflagellate cells show well-developed surface ornamentation whereas juvenile skeletons only show weak ornamentation or lack the netlike ornamentation, an opinion which is also expressed in Jerkovic (1969). Applied to the equatorial Pacific populations, this would mean that only a few skeletons are from adult cells, whereas the bulk of the former populations was built up by juvenile cells. However, observations in the equatorial Pacific, California, and the Norwegian Sea indicate a dependence of the presence of surface structures in isolated skeletons on temperature, presence of calcareous ingredients in the bottom sediments, and, most importantly, on solution. Details will be published elsewhere.

\section{SYSTEMATIC PALEONTOLOGY}

The systematic paleontology of silicoflagellates is in a rather chaotic state, as there is considerable confusion about species names owing to poor illustration and description by early authors as well as to insufficient data on the stratigraphic position of samples from which silicoflagellates were described. Fortunately the famous Ehrenberg collection survived the war. Most of Ehrenberg's silicoflagellate species are recognizable and are photographed, redrawn, and redescribed by Locker (personal communication). It seems that originals of quite a few species do not correspond to the common use of names in the more recent literature (Locker, personal communication). To avoid further confusion, species names and concepts 
TABLE 2

Distribution of Silicoflagellates at Site 316

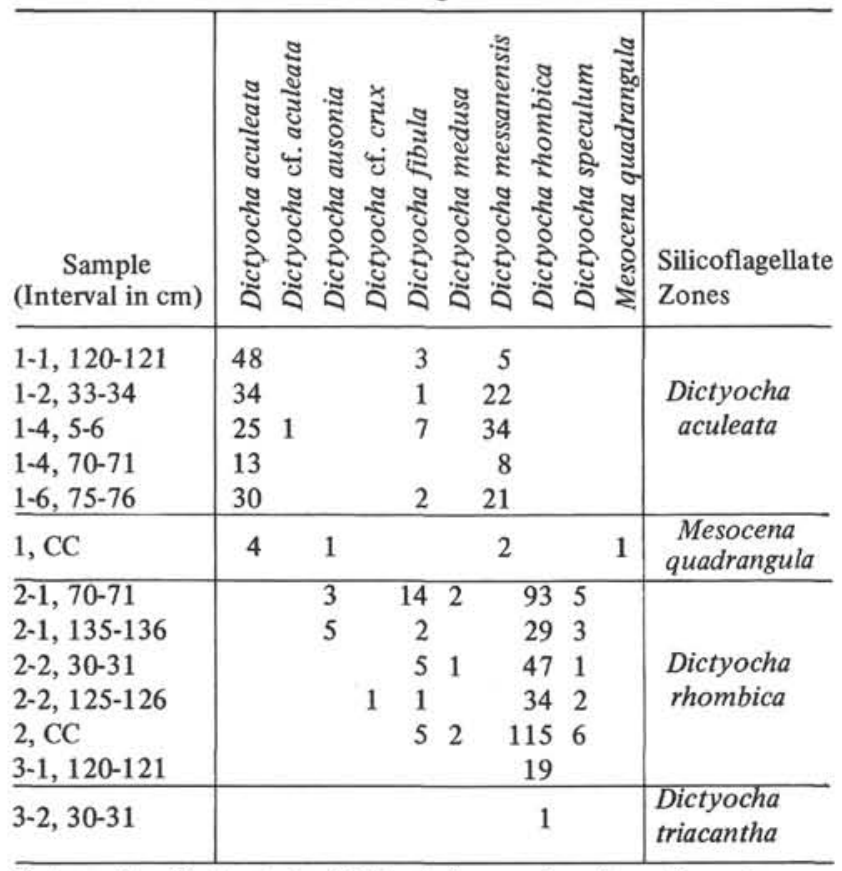

Note: See footnote in Table 1 for explanation of numbers.

used in this paper (e.g., D. fibula, D. rhombica) are the same as those in Martini, 1971, but some will probably have to be changed after the redescription of the Ehrenberg material is available.

References to the original descriptions and possible synonyms, or to more recent descriptions or illustrations of particular species are limited to a minimum, and only some remarks or short discussions are given.

\section{Genus DICTYOCHA Ehrenberg, 1839}

Dictyocha aculeata (Lemmermann)

(Plate 1, Figure 2; Plate 2, Figures 3a, b)

Dictyocha fibula var. aculeata Lemmermann, 1901, p. 261, pl. 11, fig. 1, 2.

Dictyocha fibula "var." aculeata Lemmermann, in Ling, 1970, p. 91, pl. 18, fig. 11-13.

Dictyocha fibula Ehrenberg s.l., pro parte in Martini, 1971b, p. 1696, pl. 1, fig. 5.

Dictyocha epiodon Ehrenberg, in Bukry and Foster, 1973, p. 826, pl. 2, fig. 7,8 .

Remarks: In the equatorial Pacific this species has its lowest occurrence in the upper part of the Mesocena quadrangula Zone and in standard nannoplankton Zone NN19, which is in good agreement with the range published by Ling, 1972, as occurring in the foraminifer Zone N 22 to Recent. It is the most common form in the late Pleistocene to Recent samples.

\section{Dictyocha cf. aculeata (Lemmerman)}

(Plate 1, Figure 3)

Remarks: A single specimen showing eight short secondary spines pointing outwards instead of four on the basal ring was found in Sample $316-1-4,5-6 \mathrm{~cm}$ (D. aculeata Zone). It represents most likely an aberrant specimen of $D$. aculeata.

\section{Dictyocha ausonia Deflandre}

(Plate 1, Figures 15-18)

Dictyocha ausonia Deflandre, 1941, p. 101, fig. 8-11, 13. Dictyocha rhombica (Schulz) s.l., in Martini, 1971b, p. 1697, pl. 1, fig. $9,10$.

Dictyocha ausonia Deflandre, in Ling, 1972, p. 159, pl. 25, fig. 1-10.

Remarks: D. ausonia Deflandre and D. mutabilis Deflandre seem to occur in similar strata, and according to Deflandre can be differen- tiated by their size and surface ornamentation. However, the great variation of $D$. ausonia leading to navicular forms discussed as $D$. cf. ausonia below, and the similar trend in D. mutabilis seem to indicate the identity of the two species. In D. ausonia the apical bar is longer than the connecting rods to the basal ring, whereas in D. rhombica both are of approximately equal length. Present in the D. triacantha Zone (?) of Hole 315A, in the D. rhombica Zone of Site 316, and in the D. fibula Zone (one specimen) of Hole 315A. An intermediate form between D. rhombica and D. ausonia was encountered in Sample 316-1, CC ( $M$. quadrangula Zone) and is tentatively included here.

\section{Dictyocha cf. ausonia Deflandre \\ (Plate 1, Figures 19-20)}

Remarks: Navicular forms which are within the range of D. ausonia and $D$. mutabilis according to Deflandre (1950) were found in two specimens in the D. fibula Zone of Hole 315A, but are not associated with good $D$. ausonia specimens, the last of which was found some 50 meters below the occurrences of the navicular forms (Table 2 and Figure 2).

\section{Dictyocha crux Ehrenberg \\ (Plate 1, Figure 7)}

Dictyocha crux Ehrenberg, 1840, p. 207.

Distephamus crux (Ehrenberg), in Ling, 1972, p. 164, pl. 26, fig. 9-16.

Remarks: Only two specimens with relatively long radial spines along the major axis were observed in Sample 315A-5-1, $45-46 \mathrm{~cm}$ in the possible D. triacantha Zone. The calcareous nannoplankton indicate Zone NN 5 (Sphenolithus heteromorphus Zone) for this particular sample. Identical specimens are present in the Luisian and Lower Mohnian of California and in the Experimental Mohole (Ling, 1972; Martini, 1972a).

\section{Dictyocha cf. crux Ehrenberg \\ (Plate 1, Figure 4)}

Remarks: In Sample 316-2-2, 125-126 cm a single specimen similar to $D$. crux was encountered in a population which is dominated by Dictyocha rhombica. As the apical ring is extremely small, the outline of the basal ring and length of spines are identical with the $D$. rhombica specimens present in the same sample; this specimen is only tentatively included in $D$. crux.

\section{Dictyocha fibula Ehrenberg}

(Plate 1, Figures 9, 10, 12; Plate 2, Figures 1, 4)

Dictyocha fibula Ehrenberg, 1840, p. 129

Dictyocha fibula Ehrenberg s.l., pro parte in Martini, 1971b, p. 1696, pl. 1, fig. 4, 6-7.

Dictyocha fibula Ehrenberg, in Ling, 1972, p. 160, pl. 25, fig. 11-15.

Remarks: Typical specimens of this species are common in the $D$. fibula Zone and are also present to lesser extent in the D. rhombica Zone and in the $M$. quadrangula Zone. Larger specimens (Plate 1, Figure 12) occur occasionally in the D. fibula population, and show no difference other than in size as compared with the "normal" forms. However, most fibula-like specimens encountered in the overlying $M$. quandrangula Zone and $D$. aculeata Zone tend to have a more quadrate basal ring (pl. 1, fig. 9), and radial spines of equal length, thus being similar to forms called D. fibula var. messanensis (Haeckel) by Ling, 1972 (p. 161, pl. 25, fig. 18, 19) and are included in Dictyocha messanensis.

\section{Dictyocha medusa Haeckel \\ (Plate 1, Figures 5, 6)}

Dictyocha medusa Haeckel, 1887, p. 1560, pl. 101, fig. 13, 14. Dictyocha medusa Haeckel, in Martini, 1971b, p. 1696, pl. 1, fig. 3. Dictyocha medusa Haeckel, in Bukry and Foster, 1973, p. 827, pl. 3, fig. $4,5$.

Remarks: Rare specimens corresponding to that figured on Plate 1, Figure 6 occur in the D. rhombica Zone at Hole 315A and Site 316, but were also found in the lower part of the $D$. fibula Zone and in the $D$. triacantha Zone (?) of Hole 315A. The cf.-specimen (Plate 1, Figure 5) from Sample 316-2-2, 30-31 cm (D. rhombica Zone) has a more rectangular outline and the supporting spines on the basal ring are more prominent than in the common form. 




Figure 3. Correlation of silicoflagellate zonations used in different parts of the Pacific Ocean and in Europe, and indication of equivalent nannoplankton zones.

Dictyocha messanensis Haeckel

(Plate 1, Figure 9; Plate 2, Figures 2a, b)

Dictyocha messanensis Haeckel in Peters, 1860, p. 799 (pl. 12, fig. 3-6 in Haeckel, 1862, fide Loeblich et al., 1968).

Dictyocha fibula var. messanensis (Haeckel), in Ling, 1972, p. 161, pl. 25 , fig. $18,19$.

Remarks: A single specimen was found during scanning electron microscope examination of Sample $316-1-4,5-6 \mathrm{~cm}$ (D. aculeata Zone), showing the broken base of a spine on the apical bar (Plate 2, Figures $2 \mathrm{a}, \mathrm{b})$. As mentioned under $D$. fibula, most specimens in the $M$. quadrangula Zone and $D$. aculeata Zone differ from $D$. fibula in having a more quadrate basal ring and radial spines of equal length (Plate 1, Figure 9), and are included here, although only in a very few specimens a spine on the apical bar seemed to be present when studied with the light microscope.

\section{Dictyocha rhombica (Schulz)}

(Plate 1, Figures 11, 13, 14; Plate 2, Figure 6)

Dictyocha rhombica (Schulz), in Deflandre, 1941, p. 101, fig. 1-7. Dictyocha rhombica (Schulz), in Martini, 1971b, p. 1696, pl. 1, fig. 8.

Remarks: Although common in the $D$. rhombica Zone and also present to a lesser extent in the $D$. triacantha Zone and $D$. fibula Zone, this species with a horizontal apical bar is among the most disputed forms, and it seems to be identical with D. aspera of some authors. Data from the original material of the Ehrenberg collection even indicate that the type of $D$. fibula has a horizontal bar and not a vertical bar as commonly accepted (Locker, personal communication). In the present paper specimens with a horizontal apical bar approximately equivalent in length to the lateral rods are included in " $D$. rhombica."
Specimens encountered in Hole 315A, Core 5 (D. triacantha Zone ?) are generally larger than those from the $D$. rhombica Zone. A single aberrant specimen (Plate 1, Figure 11) similar to D. triacantha Ehrenberg was found among 93 counted specimens on a smear slide of Sample 316-2-1, 70-71 cm.

\section{Dictyocha speculum Ehrenberg}

(Plate 1, Figure 8)

Dictyocha speculum Ehrenberg, 1839, p. 129, pl. 4, fig. Xn.

Dictyocha speculum Ehrenberg, in Martini, 1971b, p. 1696. pl. 1, fig. 13,14 .

Distephanus speculum (Ehrenberg), in Ling, 1972, p. 166, pl. 26, fig. 23, 24 , pl. 27 , fig. 1,2 .

Remarks: Specimens found in small numbers in the $D$. rhombica Zone of Hole $315 \mathrm{~A}$ and Site 316 and in the D. fibula Zone of Hole $315 \mathrm{~A}$ show a relatively large apical ring and two opposite basal spines much longer than the remaining ones.

\section{Genus MESOCENA Ehrenberg 1843}

\section{Mesocena quadrangula Haecke}

(Plate 1, Figure 1; Plate 2, Figures 5a, b)

Mesocena quadrangula Haeckel, 1887, p. 1556.

Mesocena polymorpha var. quadrangula Haeckel, in Lemmermann, 1901, pl. 10, fig. 5-7.

Mesocena cf. elliptica Ehrenberg, pro parte in Ling, 1970, p. 100, pl. 20 , fig. 13,14 .

Mesocena quadrangula Ehrenberg ex Haeckel, in Martini, 1971b, p. 1969, pl. 1, fig. 2 . 


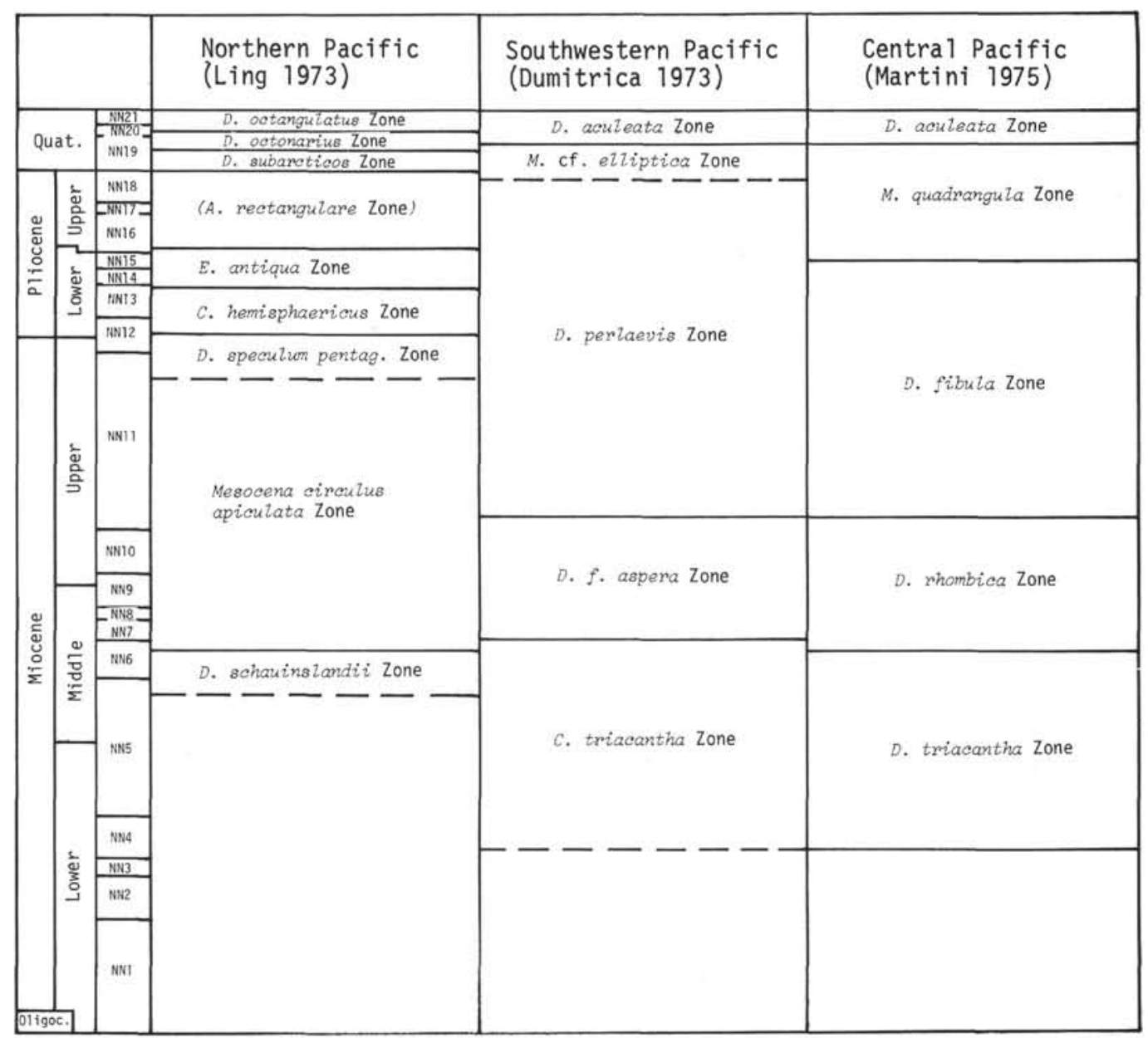

Figure 3. (Continued).

"Mesocena" cf. elliptica Ehrenberg, in Dumitrica, 1973b, p. 850, pl. 6, fig. 1.

?Mesocena eliptica Ehrenberg, pro parte in Bukry and Foster, 1973, p. 828 , tab. 3.

Remarks: The "Mesocena elliptica complex" of various authors obviously contains quite different forms and needs further study and proper differentiation. Specimens considered here show a rounded to quadrate ring with irregularly scattered knots on the surface (Plate 2, Figures $5 \mathrm{a}, \mathrm{b}$ ) clearly seen in the light microscope, and four prominent spines of equal length, arranged along the long and short axis. Further, it seems to be a stratigraphically useful species with a range restricted to the late Pliocene and most of the Pleistocene. Its last occurrence seems to be in the upper part of standard nannoplankton Zone NN19 (Pseudoemiliania lacunosa Zone) and in the upper part of the diatom Nitzschia reinholdii Zone in the Central Pacific. It was also noted by Dumitrica (1973b) in the early Pleistocene of the southwest Pacific and is present in the Western Indian Ocean (DSDP 241) in the basal Gephyrocapsa oceanica Zone (NN 20).

\section{REFERENCES}

Bachmann, A. 1970. Silicoflagellaten aus dem oberösterreichischen Egerien (Oberoligozän): Verh. Geol. Bundesanst., p. 275-305.

1971a. Silicoflagellaten aus dem Eggenburgian von Ernstbrunn (Niederösterreich): Verh. Geol. Bundesanst., p. 552-569.

1971b. Silicoflagellaten aus dem oberen Badenian von Walbersdorf, Burgenland: Sitzber. Osterr. Akad. Wiss., Math.-Nat. K1., Abt. I, p. 55-72.
Bachmann, A. and Keck, A., 1969. Die Oberflächenstruktur der Silicoflagellaten: Mikrokosmos, v. 58, p. 204-207.

Bukry, D., 1973a. Phytoplankton stratigraphy, Central Pacific Ocean, Deep Sea Drilling Project, Leg 17. In Winterer, E.L., Ewing, J.E., et al., Initial Reports of the Deep Sea Drilling Project, Volume 17: Washington (U.S. Government Printing Office), p. 871-889.

1973b. Coccolith and silicoflagellate stratigraphy, Deep Sea Drilling Project Leg 18, Eastern North Pacific. In Kulm, L.D., von Huene, R., et al., Initial Reports of the Deep Sea Drilling Project, Volume 18: Washington (U.S. Government Printing Office), p. 817-831.

1973c. Coccoliths and silicoflagellates from Deep Sea Drilling Project Leg 19, North Pacific Ocean and Bering Sea. In Creager, J.S., Scholl, D.W., et al., Initial Reports of the Deep Sea Drilling Project, Volume 19: Washington (U.S. Government Printing Office), p. 857-867.

1973d. Coccolith and silicoflagellate stratigraphy, Tasman Sea and Southwestern Pacific Ocean, Deep Sea Drilling Project Leg 21. In Burns, R.E., Andrews, J.E., et al., Initial Reports of the Deep Sea Drilling Project, Volume 21: Washington (U.S. Government Printing Office), p. 885-893.

1974a. Coccolith and silicoflagellate stratigraphy, Eastern Indian Ocean, Deep Sea Drilling Project Leg 22. In von der Borch, C.C., Sclater, J.G., et al., Initial Reports of the Deep Sea Drilling Project, Volume 22: Washington (U.S. Government Printing Office), p. 601-607. 
, 1974b. Phytoplankton stratigraphy, offshore East Africa, Deep Sea Drilling Project Leg 25. In Simpson, E.W.W., Schlich, R., et al., Initial Reports of the Deep Sea Drilling Project, Volume 25: Washington (U.S. Government Printing Office), p. 635-646.

Bukry, D. and Foster, J.H., 1973. Silicoflagellate and diatom stratigraphy, Leg 16, Deep Sea Drilling Project. In van Andel, T.H., Heath, G.R., et al., Initial Reports of the Deep Sea Drilling Project, Volume 16: Washington (U.S. Government Printing Office), p. 815-871.

Burckle, L.H., 1972. Late Cenozoic planktonic diatom zones from the Eastern Equatorial Pacific: Nova Hedw., Beiheft 39 , p. 217.

Deflandre, G., 1950. Contribution a l'étude des Silicoflagellidés actuels et fossiles: Microscopie, v. 2, p. 72-108.

Dumitrica, P., 1973a. Miocene and Quaternary silicoflagellates in sediments from the Mediterranean Sea. In Ryan, W.B.F., Hsü, K.J., et al., Initial Reports of the Deep Sea Drilling Project, Volume 13: Washington (U.S. Government Printing Office), p. 902-933.

1973b. Paleocene, late Oligocene and postOligocene silicoflagellates in Southwestern Pacific sediments cored on DSDP Leg 21. In Burns, R.E., Andrews, J.E., et al., Initial Reports of the Deep Sea Drilling Project, Volume 21: Washington (U.S. Government Printing Office), p. 837-883.

Jerković, L., 1919. Les Nouvelles recherches de la superficie du squelette des Silicoflagellidés: God. Biol. Inst. Univ. Sarajevu, v. 22, p. 129-176.

Ling, H.Y., 1970. Silicoflagellates from Central North Pacific core sediments: Am. Paleontol. Bull., v. 58, p. 85-129.

1972. Upper Cretaceous and Cenozoic silicoflagellates and ebridians: Am. Paleontol. Bull., v. 62, p. 135-229.

1973. Silicoflagellates and ebridians from Leg 19. In Creager, J.S., Scholl, D.W., et al., Initial Reports of the
Deep Sea Drilling Project, Volume 19: Washington (U.S. Government Printing Office), p. 751-775.

Loeblich, A.R. III, Loeblich,.L.A., Tappan, H., and Loeblich, A.R., Jr., 1968. Annotated index of fossil and recent silicoflagellates and ebridians with descriptions and illustrations of validly proposed taxa: Geol. Soc. Am., Mem. 106, p. 1317.

Martini, E., 1971a. Standard Tertiary and Quaternary calcareous nannoplankton zonation: Plankt. Conf. Second Rome 1970, Proc., Farinacci, A. (Ed.), Roma (Tecnoscienza), v. 2, p. 739-785.

1971b. Neogene silicoflagellates from the Equatorial Pacific. In Winterer, E.L., Riedel, W.R., et al., Initial Reports of the Deep Sea Drilling Project, Volume 7: Washington (U.S. Government Printing Office), p. 16951708.

1972a. Der stratigrapyische Wert von Silicoflagellaten im Jungtertiär von Kalifornien und des östlichen Pazifischen Ozeans: Mitt. Deutsch. Geol. Ges., v. 5, p. 47-49.

1972b. Silicoflagellate zones in the late Oligocene and early Miocene of Europe: Senckenb. Lethaea, v. 53, p. $119-122$.

1974. Silicoflagellate zones in the Eocene and early

Oligocene: Senckenb. Lethaea, v. 54, p. 527-532.

Sanfilippo, A., Burckle, L.H., Martini, E., and Riedel, W.R., 1973. Radiolarians, diatoms, silicoflagellates and calcareous nannofossils in the Mediterranean Neogene: Micropaleontology, v. 19, p. 209-234.

Wornardt, W.W., Jr., 1971. Eocene, Miocene and Pliocene marine diatoms and silicoflagellates studies with the electron microscope: Plankt. Conf. Second Rome 1970 Proc., Farinacci, A. (Ed.), Roma (Tecnoscienza), v. 2, p. 12771300. 


\section{PLATE 1}

All specimens approximately $\times 450$

Figure $1 \quad$ Mesocena quadrangula Haeckel. Sample 315-3, CC, $M$. quadrangula Zone.

Figure 2 Dictyocha aculeata (Lemmermann). Sample 316-1-4, 70-71 cm, D. aculeata Zone.

Figure 3 Dictyocha cf. aculeata (Lemmermann).

Sample 316-1-4, 5-6 cm, D. aculeata Zone.

Figure $4 \quad$ Dictyocha cf. crux Ehrenberg.

Sample 316-2-2, 125-126 cm, D. rhombica Zone.

Figure 5 Dictyocha cf. medusa Haeckel.

Sample 316-2-2, 30-31 cm, D. rhombica Zone.

Figure 6 Dictyocha medusa Haeckel.

Sample 316-2-1, 70-71 cm, D. rhombica Zone.

Figure 7 Dictyocha crux Ehrenberg.

Sample 315A-5-1, $45-46 \mathrm{~cm}$, D. triacantha Zone (?).

Figure $8 \quad$ Dictyocha speculum Ehrenberg.

Sample 316-2-1, 135-136 cm, D. rhombica Zone.

Figure 9 Dictyocha messanensis Haeckel.

Sample 316-1-4, 5-6 cm, D. aculeata Zone.

Figure 10 Dictyocha fibula Ehrenberg.

Sample 315A-2, CC, D. fibula Zone.

Figure 11 Dictyocha rhombica (Schulz), aberrant specimen. Sample 316-2-1, 70-71 cm, D. rhombica.Zone.

Figure 12 Dictyocha fibula Ehrenberg, large form.

Sample 315-3, CC, M. quadrangula Zone.

Figures 13, 14 Dictyocha rhombica (Schulz).

13. Sample 316-2-1, 70-71 cm, D. rhombica Zone. 14. Sample $315 \mathrm{~A}-3-1,35-36 \mathrm{~cm}, D$. rhombica Zone.

Figures 15-18 Dictyocha ausonia Deflandre.

15. Sample 316-1, CC, $M$. quadrangula Zone.

16. Sample $316-2-1,135-136 \mathrm{~cm}$, D. rhombica Zone.

17, 18. Sample 315A-5-1, $45-46 \mathrm{~cm}, D$. triacantha Zone (?).

Figures 19,20 Dictyocha cf. ausonia Deflandre.

19. Sample 315A-1-1, 136-137 cm, D. fibula Zone. 20. Sample 315A-1-2, 70-71 cm, D. fibula Zone. 
PLATE 1
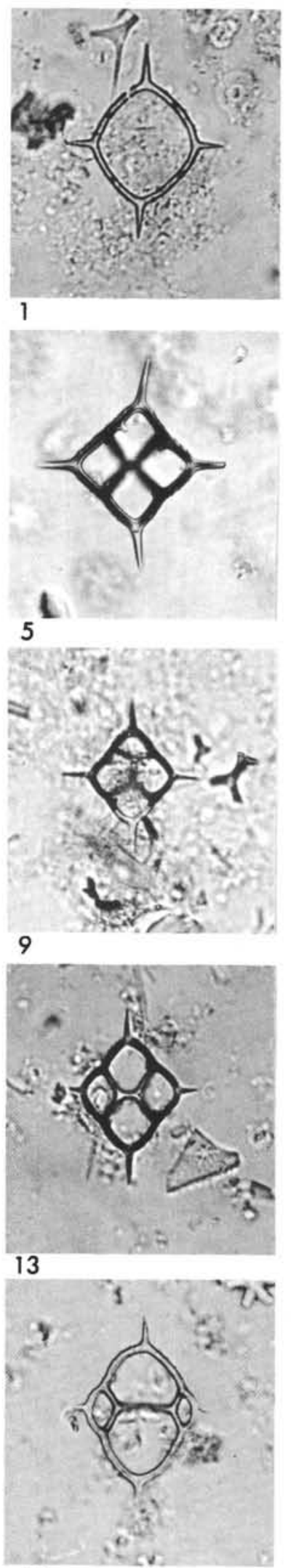

17
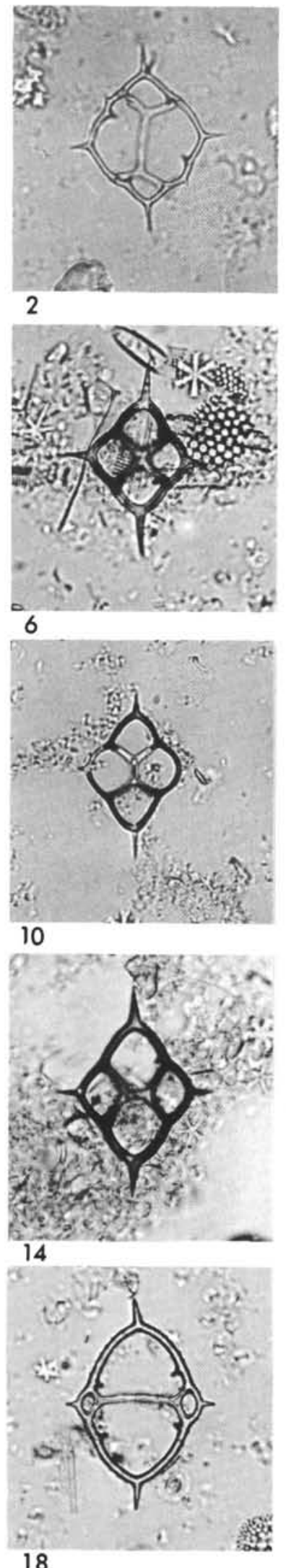
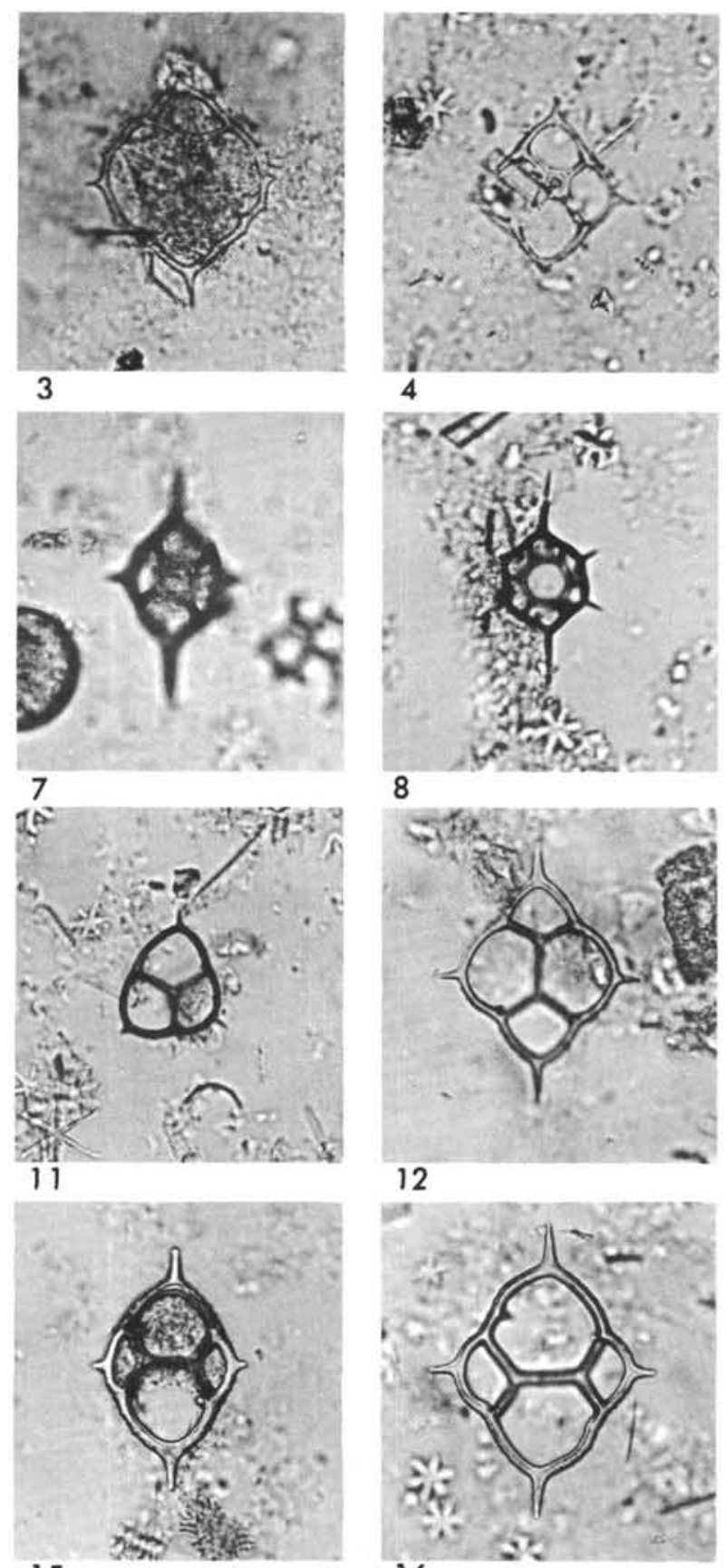

15
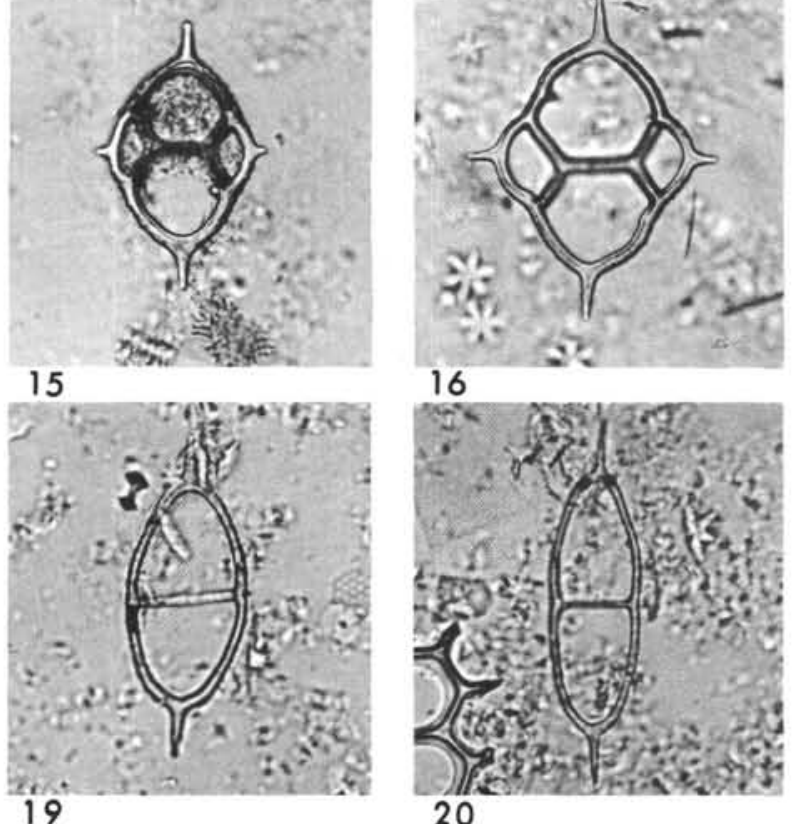


\section{PLATE 2}

Figure 1 Dictyocha fibula Ehrenberg.

Sample 315A-2-1, 80-81 cm, D. fibula Zone.

1a. SEM $1300 \times$, 1b. SEM $3250 \times$.

Figure 2 Dictyocha messanensis Haeckel.

Sample 316-1-4, 5-6 cm, D. aculeata Zone.

2a. SEM $1300 \times$. 2b. SEM $6500 \times$.

Figure 3 Dictyocha aculeata (Lemmermann).

Sample 316-1-4, 5-6 cm, D. aculeata Zone.

3a. SEM $1300 \times$. 3b. SEM $6500 \times$.

Figure 4 Dictyocha fibula Ehrenberg. SEM 1300×.

Sample 316-1-4, 5-6 cm, D. aculeata Zone.

Figure $5 \quad$ Mesocena quadrangula Haeckel.

Sample 66-A1-2, top, M. quadrangula Zone.

5a. SEM $1300 \times$. 5b. SEM $3250 \times$.

Figure 6 Dictyocha rhombica (Schulz). SEM 1200×.

Sample 66-2-2, 140-141 cm, D. rhombica Zone.

Figure 7 Coscinodiscus sp. SEM 1080X.

Sample 315A-2-1, 80-81 cm, D. fibula Zone.

Figure $8 \quad$ Roperia tesselata (Roper). SEM 650×.

Sample 316-1-4, 5-6 cm, D. aculeata Zone. 
PLATE 2
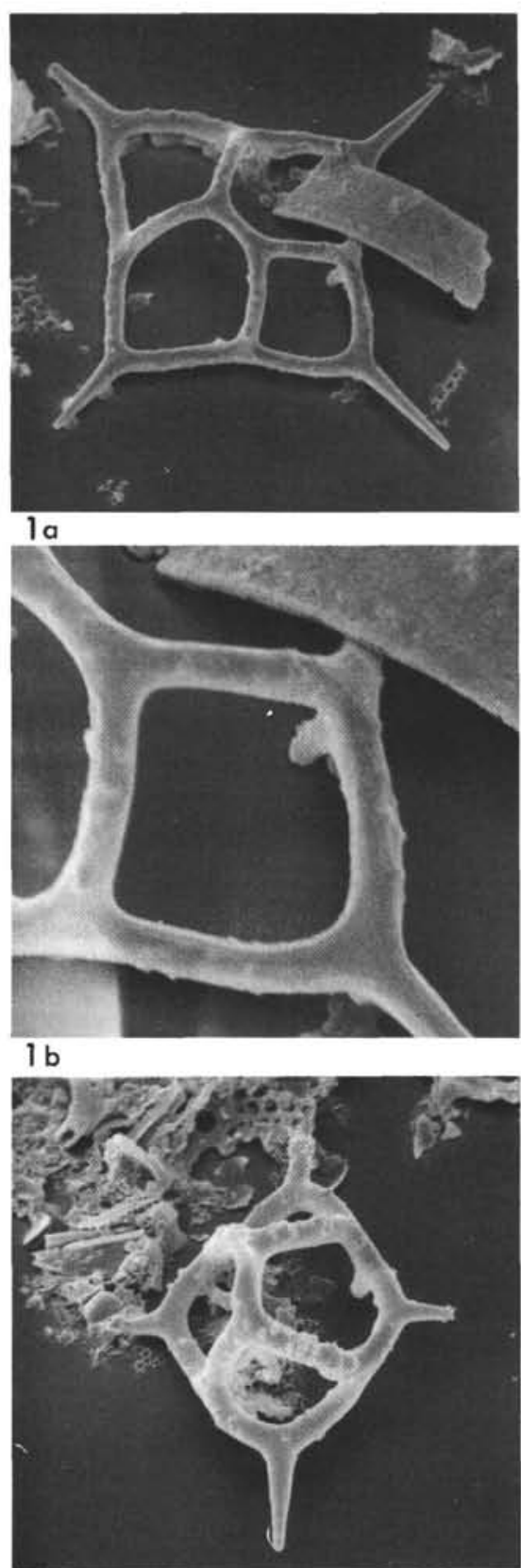

4



6
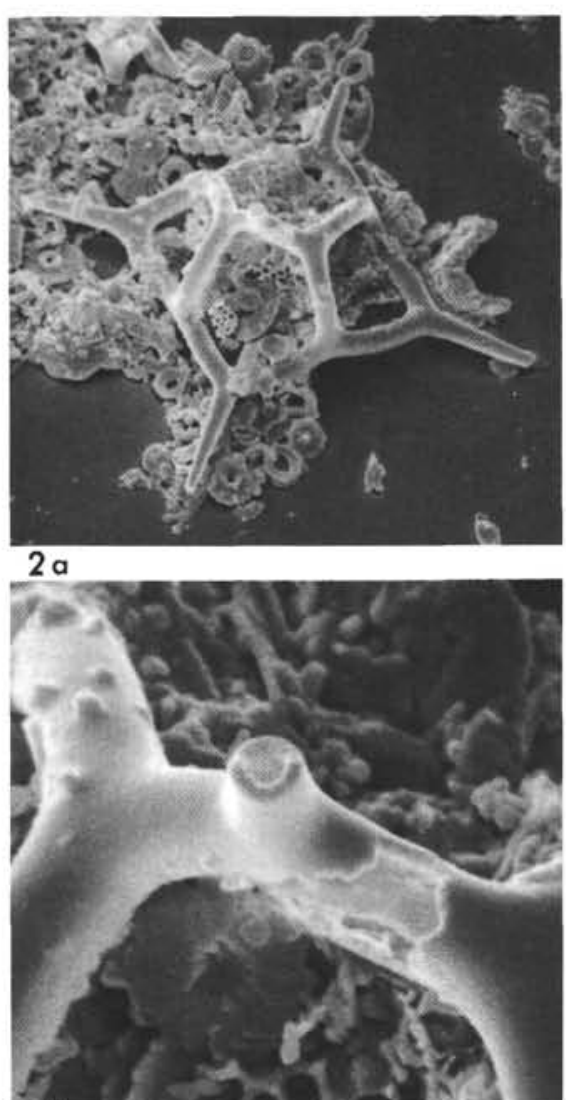

2 b

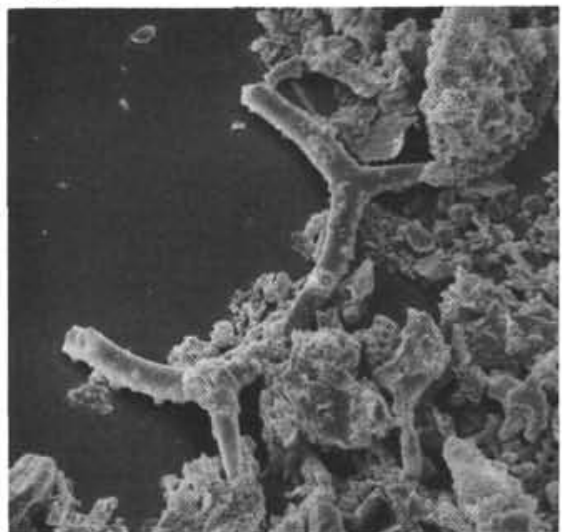

$5 \mathrm{a}$

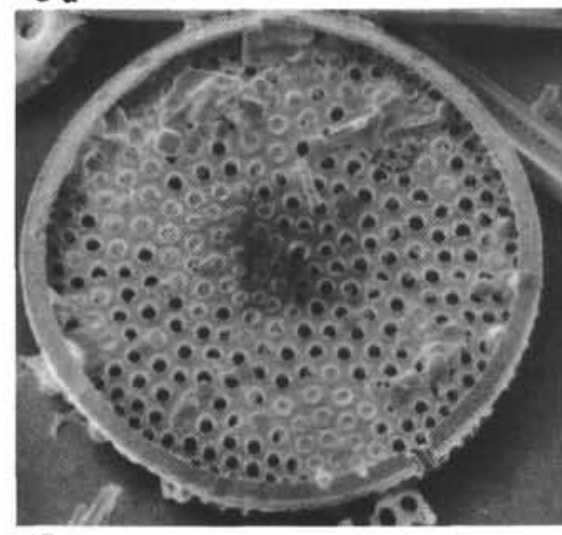

7

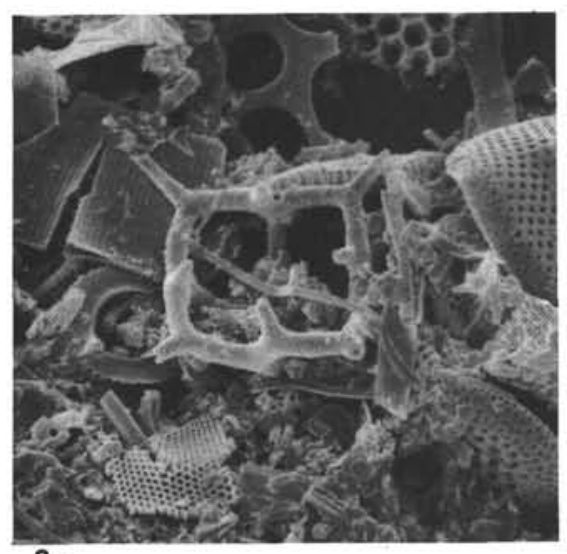

$3 a$

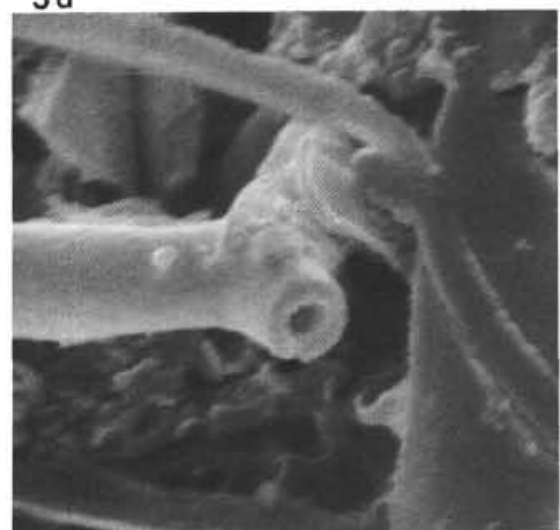

$3 b$

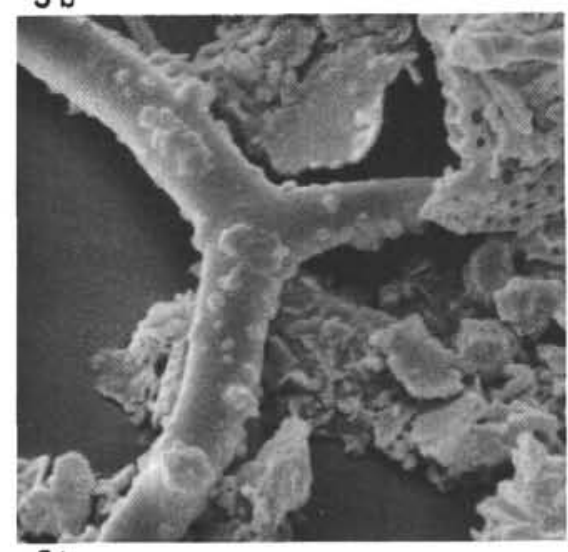

5 b

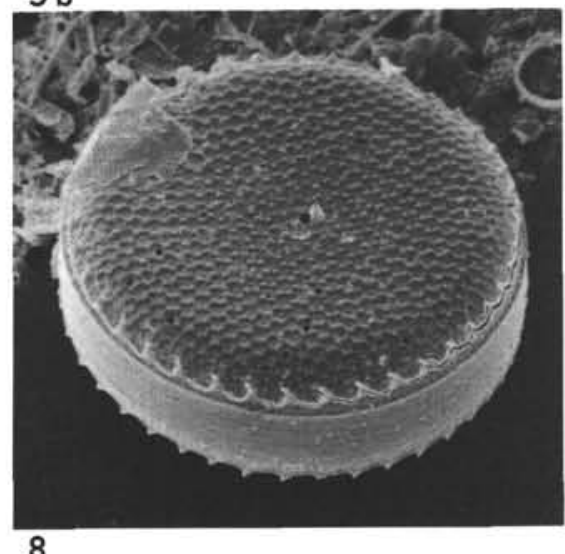

